\title{
Project Based Sukuk (PBS) and Its Implementation in Economic Development in Indonesia
}

\author{
Taufiq Kurniawan ${ }^{1} \&$ Asmak Ab Rahman²
}

\begin{abstract}
Project Based Sukuk (PBS) and Its Implementation in Economic Development in Indonesia. The Indonesian government needs funds to accelerate infrastructure development. Therefore, in 2012 Indonesia issued a PBS sukuk specifically to finance infrastructure development. This research was conducted to find out how the implementation of PBS sukuk in economic development in Indonesia is seen from the perspective of Islamic economics. Data was collected using interviews and documentation methods from primary and secondary sources. The results of this study indicate that the issuance of PBS sukuk from time to time has shown significant growth. This is indicated by the PBS sukuk budget which is increasing from year to year in line with the increasing investor interest in the shari'ah concept-used instrument. PBS's increasing budget in building national infrastructure also proves that Islamic instruments have grown in the capital market. So that it will gradually reduce the concept of usury circulating in the capital market. This phenomenon also shows that the shari'ah economy has an important role in helping the government, especially in the field of infrastructure development.
\end{abstract}

Keywords: Project Based Sukuk, shari'ah economy, the infrastructure development in Indonesia

\begin{abstract}
Abstrak: Project Based Sukuk (PBS) Serta Pelaksanaannya dalam Pembangunan Ekonomi di Indonesia. Pemerintah Indonesia membutuhkan dana untuk mempercepat pembangunan infrastruktur. Karena itu, pada tahun 2012 Indonesia menerbitkan sukuk PBS yang dikhususkan untuk membiayai pembangunan infrastruktur. Penelitian ini dilakukan untuk mengetahui bagaimana implementasi sukuk PBS dalam pembangunan ekonomi di Indonesia dilihat dari perspektif ekonomi Islam. Data dikumpulkan dengan menggunakan metode wawancara dan metode dokumentasi dari sumber primer dan sumber sekunder. Hasil penelitian ini menunjukkan bahwa penerbitan sukuk PBS dari waktu ke waktu telah menunjukkan pertumbuhan yang signifikan. Hal ini ditunjukkan dengan anggaran sukuk PBS yang semakin meningkat dari tahun ke tahun seiring dengan makin besarnya minat investor terhadap instrumen yang menggunakan konsep syariah ini. Meningkatnya anggaran PBS dalam membangun infrastruktur nasional juga membuktikan bahwa istrumen syariah telah tumbuh di pasar modal. Sehingga secara bertahap akan mengurangi konsep riba yang beredar di pasar modal. Penomena ini sekaligus juga menunjukkan bahwa ekonomi syariah memiliki peran yang penting dalam membantu pemerintah khususnya di bidang pembangunan infrastruktur.
\end{abstract}

Kata Kunci: Sukuk PBS, ekonomi syariah, pembangunan di Indonesia

${ }^{1}$ Ph.D. Candidate, Department of Syariah and Economics, Academy of Islamic Studies, University of Malaya, Kuala Lumpur - Malaysia, E-Mail:

${ }^{2}$ Senior Lecturer, Department of Syariah and Economics, Academy of Islamic Studies, University of Malaya, Kuala Lumpur - Malaysia, E-Mail:

E-mail: fathony623@yahoo.com, asmak@um.edu.my 


\section{Introduction}

Infrastructure development is part of economic development. A country that has built many public facilities provided for the service of its people can be said to be a country that cares for the people (propeople). This is because one of the tasks of the government is to serve the community to prosper them. ${ }^{1}$ When the human population increases, it means that additional public facilities are becoming increasingly needed. For the government, the current infrastructure development in Indonesia has become an urgent need. This is evident from the many infrastructures that have been built in almost all the Unitary Republic of Indonesia (NKRI).

Infrastructure development throughout the cabinet working period led by president Joko Widodo requires considerable funds. These funds are obtained from funding sources that are designed and arranged neatly and well. One of the many funds collected was obtained from an Islamic instrument, the Sukuk Project Based Sukuk (PBS). This article discusses how the implementation of PBS sukuk in economic development in Indonesia is seen from an Islamic economic perspective and how the PBS sukuk has a role in helping development in Indonesia, especially in infrastructure development. Data was collected using interviews and documentation methods from primary and secondary sources

\section{Project Based Sukuk (PBS)}

Project Based Sukuk (PBS) is a sovereign sukuk issued by the government of the Republic of Indonesia using the project as part of its underlying assets. PBS sukuk are sovereign sukuk issued specifically to finance government projects. In the formation of PBS sukuk, the number of sharia contracts is required. Among these contracts, there

${ }^{1}$ Teraik Kogoya, Benu Olfie, and Olly Esry Laoh, 'Partisipasi Masyarakat Terhadap Pembangunan Infrastruktur Jalan Desa di Kabupaten Lanny Jaya-Papua', Jurnal Berkala Ilmiah Efisiensi, 15.02 (2015), p. 1 <https://ejournal.unsrat.ac.id/index.php/jbie/article/view/8343> [accessed 23 October 2019]; Anggatia Ariza, 'Pengaruh Pertumbuhan Ekonomi dan Belanja Modal Terhadap Indeks Pembangunan Manusia (IPM) dalam Perspektif Islam', Al-Maslahah, 12.1 (2016), p. $2<$ https://doi.org/10.24260/almaslahah.v12i1.348>. 
is one main contract and several supporting contracts to form the PBS sukuk instrument. The main contract is the al-ijarah contract with the structure of the ijârah asset to be leased (Ijârah al-Maujûdât al-Mau'ùd Bistijarihâ (IMMB)). While the supporting contracts include the al-bay contract (sale and purchase), wakâlah (representative), and promises to sell and repurchase (al-wa'd bi al-bay' wa al-syira'). ${ }^{2}$

PBS sukuk is one type of sovereign sukuk that has been issued by the Indonesian government since 2012. Because PBS sukuk is part of the sovereign sukuk, the issuance method of it also uses the sharia system. The difference between non-PBS sukuk and PBS is the use of funds from the issuance of sovereign sukuk. Non-PBS sovereign sukuk are used to finance the state budget in general (general financing), specifically to cover the budget deficit. Whereas the PBS sovereign sukuk issuance is used to finance certain activities or projects carried out by the ministry or agency. In other words, the funds obtained from the issuance of sukuk are directly earmarked or devoted to financing projects that have been determined in the State Budget and Revenue (APBN) and cannot be used for other purposes. ${ }^{3}$

\section{Objectives and Benefits of Project Based Sukuk (PBS)}

As explained earlier, PBS sukuk is a sovereign sukuk that is devoted to financing government projects. The issuance of sovereign sukuk for project financing is one of the innovations developed by the government to provide an effective and efficient alternative source of project financing. The main purpose of the issuance of the sovereign sukuk is to finance infrastructure projects that have been allocated in the State Budget (APBN). ${ }^{4}$

${ }^{2}$ Dahlan Siamat, ed., Sukuk Negara: Instrumen Keuangan Berbasis Syariah, (Jakarta: Direktorat Pembiayaan Syariah, Direktorat Jenderal Pengelolaan Utang, Kementerian Keuangan RI, 2014), p. 68; Direktorat Pembiayaan Syariah, Kumpulan Fatwa Dewan Syariah Nasional Majelis Ulama Indonesia Terkait Surat Berharga Syariah Negara (Sukuk Negara), Ed. 4 (Jakarta: Kerjasama Kementerian Keuangan RI dengan Dewan Syariah Nasional - Majelis Ulama Indonesia, 2014), p. 39.

${ }^{3}$ Wurjanto Nopijantoro, 'Surat Berharga Syariah Negara Project Based Sukuk (SBSN PBS): Sebuah Instrumen Alternatif Partisipasi Publik dalam Pembiayaan Infrastruktur', Substansi: Sumber Artikel Akuntansi Auditing dan Keuangan Vokasi, 1.2 (2017), 390-406 (p. 396).

${ }^{4}$ Siamat, ed., p. 178. 
The benefits that can be obtained from the issuance of sovereign sukuk to finance projects include: First, diversification of APBN funding sources. Through sovereign sukuk instruments issued in the context of project financing, the government has several alternative sources of financing, especially those originating from the issuance of Government Securities (SBN). Second, accelerate the process of building infrastructure projects. Third, fostering a nation that can be independent in carrying out national development. This is because the public can directly participate in financing government projects through the purchase of sovereign sukuk. Fourth, develop Islamic financial markets. The issuance of sovereign sukuk for project financing takes the growth phase of Islamic finance in Indonesia to a higher stage. ${ }^{5}$ Fifth, improve public services. The issuance of sovereign sukuk for project financing is also expected to further improve public services, especially in providing funding sources for infrastructure development. Sixth, increase transparency in government activities. In line with sharia financial principles that encourage transparency in all its activities, the issuance of sovereign sukuk instruments based on sharia is expected to further encourage transparency in government activities. ${ }^{6}$

\section{Project Based Sukuk (PBS) Issuance Process}

When the PBS sukuk will be issued, the government first asks DSN-MUI's sharia opinion about sukuk that is structured using the IMMB concept. After a thorough review of several things including: the structure of the sukuk used, the contracts and agreements contained in the issuance of the sukuk, as well as other documents including the method and process of issuance, those who have authority and expertise in the sharia field state that the sukuk issued not contrary to Islamic principles. $^{\text {? }}$

After PBS obtains Shariah opinion, then, the government no longer needs to ask Sharia opinion from DSN-MUI for the issuance of the following series. Even so, the government still has to follow the

\footnotetext{
${ }^{5}$ Siamat, ed., pp. 178-79.

${ }^{6}$ Siamat, ed., p. 179.

${ }^{7}$ Siamat, ed., p. 34.
} 
guidelines and rules regarding the issuance of PBS sukuk that have been set previously.

When the government requires additional funds to finance infrastructure and has confirmed the number of costs required, the government will issue PBS sukuk by auction sale which will be announced several days in advance. The auction winners will be announced after a few days the announcement of the sale of sukuk by auction is closed. ${ }^{8}$

\section{Project Based Sukuk (PBS) in Infrastructure Development in Indonesia}

\section{a. Economic Development in Indonesia}

Former chairman of the Indonesian Ulema Council (MUI), KH. Ma'ruf Amin, once stated that Indonesia, with its inhabitants who embrace various religions, is a dar al-'ahdi state (state of agreement), not dâr al-Islâm (Islamic state), not dâr al-kufr (kafir state), and not also dâr al-harbi (war state). Indonesia is not the first country to use the concept of the state of dâr al-ahdi which was built by various parties with different religious backgrounds. In 622, the Prophet Muhammad first used the concept of the Islamic state while settling in Medina. The Prophet Muhammad, together with the Muslims of Medina and adherents of religions other than Islam, made a mutual agreement known as the "Charter of Medina". This charter is a legal agreement that must be obeyed by all religious adherents in Medina.?

In the context of Indonesia, as a country where the majority of the population is followers of Islam, even the largest in the world, Indonesia is obliged to carry out economic development supported by adherents of Islam who are in Indonesia, both as leaders (government) and as people. This is because developing the economy of a region or country is a compulsory case. Economic development (al-tanmiyyah al-iqtishâdiyyah) formerly known as earth prosperity ('imârah al-ardh) is a duty from Allah

\footnotetext{
${ }^{8}$ Manggiarto, D.S, issue PBS sukuk, in an interview, 2015.

9 'KH Ma'ruf Amin: Indonesia Bukan Negara Islam, Tetapi Negara Kesepakatan' <https:// nasional.kompas.com/read/2017/10/10/08462301/kh-maruf-amin-indonesia-bukan-negara-islamtetapi-negara-kesepakatan> [accessed 23 March 2019].
} 
(taklîf syar'i) to mankind, as the word of God concerning the prosperity of the earth in surah al-Hûd 11: 61. ${ }^{10}$ Therefore, all economic development policies carried out by the Indonesian government as long as it has good aims and does not conflict with Islamic sharia, it is obligatory for all Indonesian Muslim communities to support the policy.

Aside from upholding virtue (al-amr bi al-ma'rûf) and prohibiting evil (al-nahy 'an al-munkar) for people's lives, the Government has a very important role to optimize economic development for the welfare of its people. One model of government that upholds virtue is if the government supports, helps and thinks about obtaining sources of funds for the economic development of its people. A trustworthy government is a government that does not want its people to continue to live in poverty and poverty.

Among the characteristics of an Islamic government, although the State is not based on Islamic Sharia, is when the government makes it easy for its people to perform worship, by building mosques, hajj halls, religious affairs offices, marriage halls, and so on.

Concerning economic development, the Indonesian government has practiced the characteristics of an Islamic government by making some policies that make it easy for its people to practice religious

\footnotetext{
${ }^{10}$ Allah Says:
}

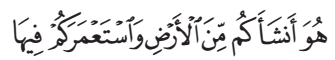

"... He (Allah) created you from earth (land) and made you prosperous [meaning: human beings are made to be the inhabitants of the world to rule over and prosper the world] ..." (Al-Hud 11: 61)

The word isti mâr (verb: ista'mara) means a request, demand, or command (țalab) from Allah so that humans create prosperity on earth through development efforts. Demands (talab) absolutely from God is a demand that the law is obligatory to be carried out by humans. Tira Nur Fitria, 'Kontribusi Ekonomi Islam dalam Pembangunan Ekonomi Nasional', Jurnal Ilmiah Ekonomi Islam, 2.03 (2016), p. $30<$ https://doi.org/10.29040/jiei.v2i03.3>. For example the implementation of prayer. Correct prayer can prevent a person from deeds and despicable nature, and keep him from all evil. In other words, this can pray can lead and encourage someone to always do good deeds and noble character. Allah Says:

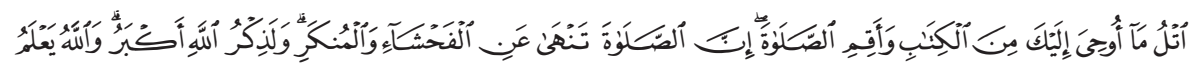

"Read along (O Muhammad) on what is revealed to you from the Koran, and establish prayer (diligently); In fact, the prayer prevents from cruel and evil deeds; and indeed remembrance of Allah is greater (its benefits and effects); and (remember) Allah knows what you are doing" (Al-Ankabut 29:45) 
teachings. Through sukuk financing that took place during 2013-2017, the government built several facilities that support the interests of Muslims such as: Mosques, Hajj dormitories, religious affairs offices, marriage halls, school buildings or campuses that are Islamic State Universities (UIN). Besides, the government also built public facilities such as the construction of dual tracks and elevated railroad tracks, roads and flyovers, and management of water resources. ${ }^{11}$ All of that is a form of economic development that is directed to prosper the earth (imârah al-ardh).

\section{b. The Need for Infrastructure Projects in Indonesian Development}

In the perspective of Islamic economics, development must be carried out based on prioritizing the urgent development needs (dhharûriyyah)

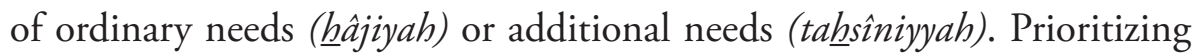
economic development for ordinary situations compared to urgent situations is a form of injustice in attitude or policy. For example, a country builds two very fancy football stadiums in one city, even though in that city there are still many roads that are damaged and difficult for vehicles to go to work, markets, schools, mosques and so on. This example is a form of economic development injustice because it puts things first and doesn't put things first.

Infrastructure has a very important role for the Indonesian economy. This is because economic growth in Indonesia is affected by the availability of infrastructures such as electrification, paved roads and clean water. The existence of development and the availability of infrastructures such as electricity, roads and clean water, play an important role in the pace of economic growth in Indonesia. If the government's role in infrastructure procurement is not yet optimal, it can be ensured that the smooth development of the economy will encounter many obstacles. ${ }^{12}$

${ }^{11}$ Eri Hariyanto, 'Efektivitas Penerbitan Sukuk Negara Sebagai Instrumen Pembiayaan APBN', Indonesian Treasury Review: Jurnal Perbendaharaan, Keuangan Negara Dan Kebijakan Publik, 2.1 (2017), 79-98 <https://doi.org/10.33105/itrev.v2i1.15>.

${ }^{12}$ Novi Maryaningsih, Oki Hermansyah, and Myrnawati Savitri, 'Pengaruh Infrastruktur Terhadap Pertumbuhan Ekonomi Indonesia', Buletin Ekonomi Moneter dan Perbankan, 17.1 (2014), 62-98 (pp. 67-68) <https://doi.org/10.21098/bemp.v17i1.44>. 
During President Joko Widodo's administration, the Indonesian government focused its attention on accelerating infrastructure development. The purpose of the acceleration of infrastructure development policy is to create higher economic growth. At present, the condition of Indonesia's infrastructure is far from ideal, and even tends to be bad. Therefore, the government is concentrating back on infrastructure development, whether in the form of road construction, toll road construction, port construction, or airport development in areas that need it. ${ }^{13}$

A decent and adequate infrastructure condition is believed to be able to increase the acceleration of a country's economic and social development. Improvements in electricity, transportation and telecommunications infrastructure can directly reduce production costs and reduce the time needed to carry out economic activities, which then has an impact on increasing productivity and production capacity of economic actors in a country. ${ }^{14}$

President Joko Widodo believes that it is impossible for the Indonesian nation to become a developed nation, if the people's houses in all corners of the archipelago cannot enjoy electricity. It is difficult for Indonesia to become the world's maritime axis if Indonesia does not have ports to lean on large ships that transport homemade products. Likewise, it is difficult to become a sovereign nation in the field of food, if the number of ponds and irrigation channels that irrigate agricultural lands throughout Indonesia is very limited. ${ }^{15}$ This illustration shows that the existence of infrastructure for the public interest is very necessary for the welfare of the Indonesian people while making Indonesia able

13 'Presiden Jokowi: Infrastruktur Untuk Pertumbuhan Ekonomi Lebih Tinggi' <https:// www.kemenkeu.go.id/publikasi/berita/presiden-jokowi-infrastruktur-untuk-pertumbuhan-ekonomilebih-tinggi/> [accessed 23 March 2019].

${ }^{14}$ Erika Sefila Putri dan Wisudanto, 'Struktur Pembiayaan Pembangunan Infrastruktur di Indonesia Penunjang Pertumbuhan Ekonomi' (presented at the Simposium I Jaringan Perguruan Tinggi untuk Pembangunan Infrastruktur Indonesia, Paper, Simposium I Jaringan Perguruan Tinggi untuk Pembangunan Infrastruktur Indonesia, 2016), pp. 222-28; Andrio Firstiana Sukma, 'Efek Pengganda Infrastruktur Pekerjaan Umum dalam Perekonomian Provinsi Bali (Multiplier Effect of Public Works Infrastructure in Bali Province)', Journal of Regional and City Planning, 26.2 (2015), 100-110-110 (p. 102) <https://doi.org/10.5614/jpwk.2015.26.2.3>.

15 'Presiden Joko Widodo' <https://www.facebook.com/story.php?story_fbid=7563357845 552738id=390581294464059> [accessed 23 March 2019]. 
to compete with other more developed countries. ${ }^{16}$

The availability of good infrastructure will affect economic growth. ${ }^{17}$ Through the creation of relations between regions will spur labor mobility between regions while at the same time will encourage the realization of equitable development. With the availability of adequate infrastructure will encourage the formation of new investments, new jobs, which means creating an increase in community income. Likewise, the availability of energy and transportation infrastructure can encourage the transfer of natural resources from surplus areas to deficient regions. ${ }^{18}$ Thus, the equalization of infrastructure development will affect the increase in income when there is an increase in productivity and development of investment funds carried out by economic actors. ${ }^{19}$

Viewed from this perspective, infrastructure development in Indonesia currently should occupy the main position in economic development in Indonesia and needs to be resolved immediately, because what is built is strategic infrastructure that is needed to improve the economy of the Indonesian people.

\section{c. Indonesian Economic Development Financing Sources}

Community participation in APBN financing can be done through two sides, namely on the revenue side and the financing side. In terms of

16 Totok Wahyu Abadi, Nunung Prajarto, and dan Budi Guntoro, 'Performance E-Government Untuk Peningkatan Partisipasi Masyarakat dalam Pembangunan Infrastruktur di Kabupaten Sidoarjo', Jurnal Kawistara, 4.3 (2014), p. 238 <https://doi.org/10.22146/ kawistara.6379>.

${ }^{17}$ Fiona Lamari and Meilita Evita Ayomi Dita Rarasati, 'An Exploratory Study of Sukuk Utilisation for Transportation Infrastructure Development in Indonesia', Makara Journal of Technology, 22.1 (2018), 53-59 (p. 53) <https://doi.org/10.7454/mst.v22i1.3581>; Hayat Abdullah, 'Realokasi Kebijakan Fiskal: Implikasi Peningkatan Human Capital dan Pembangunan Infrastruktur terhadap Pertumbuhan Ekonomi dan Kesejahteraan Masyarakat', Jurnal Bina Praja: Journal of Home Affairs Governance, 6.2 (2014), 117-28 (pp. 124-25) <https://doi.org/10.21787/ jbp.06.2014.117-128>."

18 Waluyo Zulfikar, 'Dampak Sosial, Ekonomi dan Politis dalam Pembangunan Bandara Udara Kertajati di Kabupaten Majalengka', Jurnal Caraka Prabu, 1.01 (2017), 58-77 (p. 59); Adris A. Putra and Susanti Djalante, 'Pengembangan Infrastruktur Pelabuhan dalam Mendukung Pembangunan Berkelanjutan', Jurnal Ilmiah Media Engineering, 6.1 (2016), p. $434<\mathrm{https} / / /$ ejournal.unsrat.ac.id/index.php/jime/article/view/11627> [accessed 23 March 2019].

${ }^{19}$ Wisudanto, p. 222. 
revenue, the contribution of citizens to the state budget in the form of taxes is mandatory for people who can comply with statutory regulations. This tax payment obligation can also be accompanied by threats of punishment for those who neglect them. ${ }^{20}$

The second alternative is through the financing side. From this side, the active role of the community is not mandatory or voluntary and the benefits obtained can be directly received because it is in the form of yields. Its form can be in the form of the purchase of sovereign sukuk, or with a collaboration scheme between the government and the private sector (public-private partnership). In the context of community participation, a possible and existing scheme is to purchase bonds that are conventional in nature or with Islamic sovereign sukuk. ${ }^{21}$

\section{d. Infrastructure Project Financing Strategy in Indonesia}

In the previous section, it was explained that one way to increase the economic growth of a country is through infrastructure development. As with other projects, infrastructure projects are inseparable from the need for funds. Because funds have an important role in infrastructure development, the Government must have an appropriate and appropriate strategy in encouraging community involvement to meet these needs. ${ }^{22}$ Without the support of a good financing concept, infrastructure development will produce a debt trap for the country. This means that infrastructure development takes into account the financing structure and mature investment concept so that it can produce a positive multiplier effect for the country. ${ }^{23}$

In the early days, the orientation of the issuance of sovereign sukuk was more directed at covering the state budget deficit. Such an orientation is permissible because the Indonesian government needs funds that can sustain the needs of very large state expenditure, while tax revenues have

${ }^{20}$ Wurjanto Nopijantoro, pp. 390-91.

${ }^{21}$ Nopijantoro, “'Surat Berharga Syariah Negara Project Based Sukuk (SBSN PBS),' p. 391.

${ }^{22}$ Ferdy Posumah, 'Pengaruh Pembangunan Infrastruktur Terhadap Investasi di Kabupaten Minahasa Tenggara', Jurnal Berkala Ilmiah Efisiensi, 15.3 (2015), Pp. 1-2 <Https://Ejournal. Unsrat.Ac.Id/Index.Php/Jbie/Article/View/8776> [Accessed 23 March 2019].

23 Wisudanto, p. 222. 
not been able to meet these needs. Legally, this is no problem. However, the multiplier effect on the national economy will not be too large, especially if the funds obtained are used to finance routine government operational activities. Therefore, in addition to covering the APBN deficit, the orientation of the issuance of sovereign sukuk must also be directed as a source of investment for infrastructure development in the fields of transportation, telecommunications, energy, and others. ${ }^{24}$

Economically, the multiplier effect that can result from infrastructure development will be very large. For example, the issuance of sovereign sukuk for the construction of ports in Eastern Indonesia and other strategic areas will have a significant impact on the development of domestic industries. Likewise, airport infrastructure, toll roads between regions, especially in large islands such as Sumatra, Kalimantan, and Sulawesi, and other projects, will encourage increased trade traffic both in terms of exports and imports. All of that can be realized through sovereign sukuk. ${ }^{25}$

\section{e. Infrastructure Project Financing through PBS Sukuk Issuance}

For the sovereign sukuk to provide direct benefits for infrastructure development, the Indonesian government has developed a series of sovereign sukuk that are specifically issued to finance project development. On October 11, 2011, the government for the first time auctioned off sovereign sukuk based on projects, known as PBS sukuk. PBS Sukuk which are auctioned first is PBS001 series Sukuk and PBS002 series. ${ }^{26}$

Furthermore, PBS series sovereign sukuk are issued regularly through sovereign sukuk auctions in 2012. An issuance is a form of implementation of the APBN financing strategy through the issuance of sovereign sukuk. In 2013 the government began issuing sukuk based on certain project areas or was specific to certain projects listed in the $\mathrm{APBN}$. The issuance of sovereign sukuk based on the specific project

${ }^{24}$ Irfan Syauqi Beik, 'Memperkuat Peran Sukuk Negara dalam Pembangunan Ekonomi Indonesia', AL-INFAQ, 2.2 (2011), pp. 68-69 <http://ejournal.uika-bogor.ac.id/index.php/alinfaq/article/view/80> [accessed 23 March 2019].

${ }^{25}$ Beik, p. 69.

${ }^{26}$ Siamat, ed., p. 72. 
has received a good reception from various parties and is considered as a solution to the lack of financing of infrastructure projects that require large funds. ${ }^{27}$

PBS Sukuk is divided into two versions, namely the first sukuk with the underlying project mechanism, and the second sukuk with the project financing mechanism. Sukuk issued with the underlying project mechanism is used to finance the general state budget (general financing). Whereas sukuk issued under the project financing mechanism is used specifically to finance certain projects planned in the APBN. This second PBS sukuk is relevant to the latest developments because the government needs very large amounts of funds to build various infrastructures in the territory of Indonesia. The aim is to catch up with the quantity and quality of infrastructure in various sectors in countries in ASEAN rankings such as Malaysia and Thailand. ${ }^{28}$

In the 2014-2015 report of The Global Competitiveness Report from The World Economic Forum, Indonesia's infrastructure competitiveness scored 4.4 and ranked 56th out of 144 countries. This achievement is still behind some other ASEAN countries, such as Malaysia (score 5.5, rank 25), Singapore (score 6.5, rank 2), and Thailand (score 4.6, rank 48). ${ }^{29}$ In The Global Competitiveness Report 2017-2018, Indonesia's infrastructure competitiveness score increased to 4.5 and ranked 52 out of 137 countries. Likewise for 2017-2018, although Indonesia’s ranking has again increased compared to 2014-2015, however, Indonesia is still behind Malaysia (score 5.5, rank 22), Singapore (score 6.5, rank 2), and Thailand (score 4.7, rank 43). ${ }^{30}$

The Government of Indonesia is aware that the problem of infrastructure availability is one of the main obstacles faced by investors when going to do business in Indonesia. For this reason, the Government of Indonesia has worked hard to overcome this problem since 2015 by

\footnotetext{
${ }^{27}$ Siamat, ed., pp. 72-73.

${ }^{28}$ Nopijantoro, “'Surat Berharga Syariah Negara Project Based Sukuk (SBSN PBS), p. 391.

${ }^{29}$ Klaus Schwab, Ed., The Global Competitiveness Report 2014-2015, (Geneva: The World Economic Forum, 2014), pp. 214, 260, 334, 360.

${ }^{30}$ Klaus Schwab, Ed., The Global Competitiveness Report 2017-2018 (Geneva: The World Economic Forum, 2017), pp. 148-49, 192-93, 286-87, 262-263.
} 
raising the state budget for infrastructure development. ${ }^{31}$ This can be seen from the data displayed in the graph below:

\section{Diagram1: Infrastructure Badget in APBN 2013-2018 (Trillion Rupiahs)}

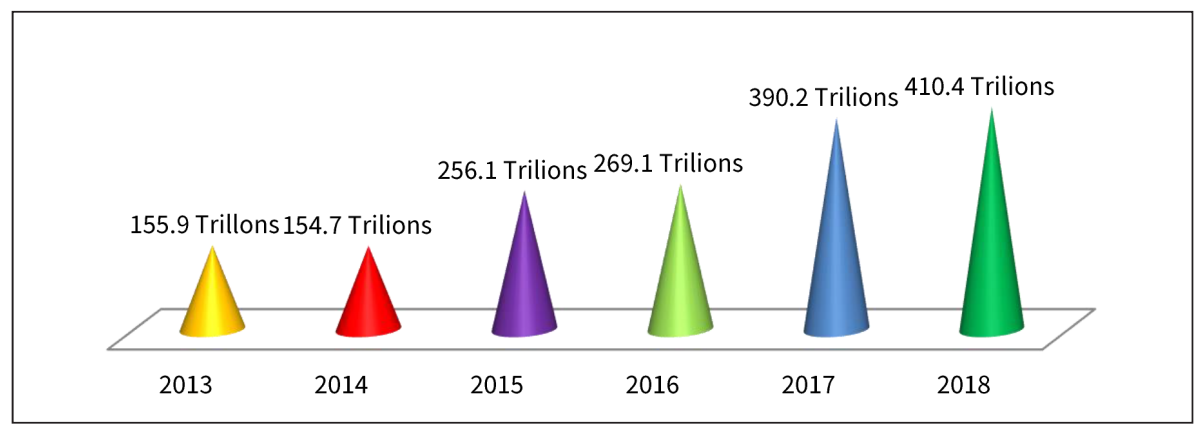

Source: APBN Directorate, Directorate General of Budget

Although debt for infrastructure development in Indonesia is not forbidden, ${ }^{32}$ as much as it is not in conflict with the provisions of the shari'a, the policy actions need to be reduced, even if necessary abandoned. For this reason, alternative financing for infrastructure development can be obtained through sukuk, which is better than direct debt. The main reason is, based on experience so far, lending countries tend to require various conditions that may be detrimental to Indonesia. Moreover, from the standpoint of equality relations between the state and the sovereignty of Indonesia, Indonesia's position will be a bit "lower" in international diplomacy, because it has a "stamp" as a debtor country. This is different from sukuk, where the equality relationship between Indonesia and investors is more visible. Foreign interventions that are detrimental to the state can also be minimized, and the state can better manage its potential sources. ${ }^{33}$

${ }^{31}$ Directorate of State Budget Development, Directorate General of Budget, 2018 State Budget Information, ed. Director of APBN Preparation (Jakarta: Directorate General of Budget, 2018), 19. For 2019 budget requirements for infrastructure development are expected to exceed Rp.4,700 trillion, read: Nopijantoro, 'Surat Berharga Syariah Negara Project Based Sukuk (SBSN PBS),' pp. 391-92.

${ }^{32}$ Muhammad Hisyam Mohamad, 'Pendekatan Islam dalam Pengurusan Hutang', in Paradigma Ekonomi \& Integrity: Sudut Pandang Islam (Kuala Lumpur: Penerbit Institut Kefahaman Islam Malaysia (IKIM), 2014), pp. 26-27 (pp. 26-27).

${ }^{33}$ Beik, p. 71; Arie Rachmat Soenjoto and Hilda Lutfiani, 'Konsep dan Aplikasi Sukuk 


\section{f. Legal Loans or Collecting Funds through PBS Sukuk Instruments for Infrastructure Development}

There are differences of opinion among Muslim economists in looking at sukuk, whether it is an investment instrument or debt instrument. Some parties classify it into investment instruments ${ }^{34}$ while others consider it a debt instrument. ${ }^{35}$ Regardless of whether the sukuk instrument is considered a debt instrument or an investment instrument, it still means that the sukuk issuer is the party that needs money to finance certain purposes. It can also be said that the sukuk issuer does not have enough money, even does not have the money to build the project. Then in such circumstances, is it justified for sukuk issuers to owe or raise money to build infrastructure? This question also applies to the Indonesian government as a sukuk issuer. In Islamic law, is the government justified to owe or collect money by issuing PBS sukuk to build infrastructure in Indonesia?

As previously discussed, economic development is a compulsory case, including infrastructure development. This is because the government should meet the needs of the people and improve the quality of their lives. While the construction of infrastructure that is built based on community needs is one way to prosper the earth, as God says ${ }^{36}$ :

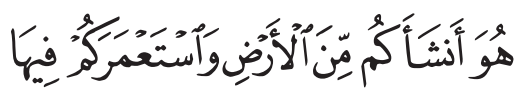

He (Allah) created you from earth (land) and made you prosperous [meaning: human beings are made to be the inhabitants of the world to rule over and prosper the world. (Al-Hud 11: 61)

\footnotetext{
Negara dalam Pembiayaan Defisit APBN di Indonesia', Islamic Economics Journal, 2.2 (2016), pp. 83-84 <https://doi.org/10.21111/iej.v2i2.1389>.

${ }^{34}$ Norma Rosyidah, 'Optimalisasi Fungsi Barang Milik Negara (BMN) Melalui Sukuk Sebagai Instrumen Pembiayaan Nasional', Jurnal Ekonomi dan Bisnis Islam (Journal of Economics and Business Islamic), 1.2 (2016), 161-72 (P. 162) <Https://Doi.Org/10.20473/Jebis.V1i2.1436>; Ika Indriasari, 'Analisis Pemilihan Sukuk Sebagai Instrumen Investasi', Stability: Journal of Management and Business, 1.1 (2018), P. 95 <Https://Doi.Org/10.26877/Sta.V1i1.2619>; Anna Nurlita, 'Investasi di Pasar Modal Syariah dalam Kajian Islam’, Kutubkhanah, 17.1 (2015), 1-20 (p. 9).

${ }^{35}$ Dzubaidah Bt Zainal Abidin dan S. Shahida, 'Sukuk "Asset-Based" Berbanding Sukuk "Asset-Backed”: Kes Kemungkiran Sukuk"' (Paper, Persidangan Kebangsaan Ekonomi Malaysia ke VIII (PERKEM VIII), 2019), p. 1.

36 Surtahman Kastin Hasan dan Sanep Ahmad, Ekonomi Islam: Dasar dan Amalan, Ed. 2 (Kuala Lumpur: Dewan Bahasa dan Pustaka, 2005), pp. 330-33.
} 
Discussion of accounts payable and debts, if considered, is included in the chapter al-mu'âmalât. In the perspective of sharia, no text suggests someone owe. However, there are texts which show that it is not wrong for someone to owe. The verse first makes a guideline in debt. As the longest verse in the Qur'an in verse 282 of Surah al-Baqarah which explains the need to record debts. Although the verse is related to the need to record accounts payable but also shows indirectly that it is not wrong if someone wants to owe.

Debt is an act that is permissible in Islam, but the ability to repay the debt must also be a consideration for those who want to owe. ${ }^{37}$ The ability to owe can be linked in meeting the needs of the principle (dhharûriyyah) to achieve the maqâshid al-syar 'iyyah (the purpose of the sharia), which is to maintain the benefit of the people of the world and the hereafter. ${ }^{38}$

If the purpose of Islamic law is related to the dharûriyyah ideology (basic necessity), hâjiyah (ordinary necessity) or tabsinniyyah (additional necessity), then in the chapter relating to this debt (the purpose of debt), it can also be related to this understanding. Therefore, actions or policies for the debt must take into account several aspects, including the stage of need in debt, whether it falls into the category of dharûriyyah, hâjiyah or tahsiniyyah. If the need for debt is included in the category of basic needs, then there is no reason to say it is something that is prohibited by the shari'a. This is to maintain the continuity of religious

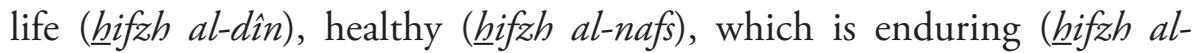

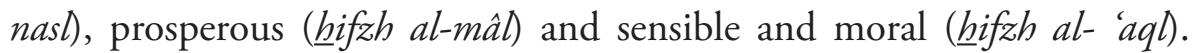
The five above are nothing but to achieve the maqâshid al-syariyyah (the purpose of the sharia), which is to maintain the benefit of the people in the world and the hereafter.

In PBS sukuk practices that apply in Indonesia, the funds collected are used to finance the construction of infrastructure/public facilities such as: Hajj boarding houses, religious affairs offices, marriage halls,

37 Winda Afriyenis, 'Perspektif Ekonomi Islam Terhadap Utang Luar Negeri Pemerintah dalam Pembangunan Ekonomi Indonesia', Maqdis : Jurnal Kajian Ekonomi Islam, 1.1 (2016), 1-16 (P. 11)."

${ }^{38}$ Mohamad, pp. 26-27. 
schools or the campus of the State Islamic University (UIN), including double track and track railroad overpasses, roads and flyovers, water resources ${ }^{39}$, and airports. ${ }^{40}$ Construction of the Hajj boarding house, religious affairs office, marriage hall, religious schools and the campus of the State Islamic University (UIN) were carried out to maintain the continuity of religious life ( $\underline{h}$ ifzh al-dîn). Development of water resources is carried out to maintain the continuity of a healthy life ( $\underline{h} i f z h$ al-nafs). The construction of a marriage hall is also carried out to maintain a sustainable life ( hifzh al-nasl). Development of water resources is also

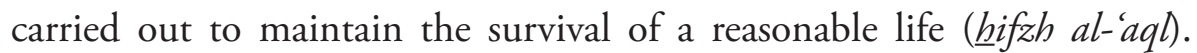
While the construction of transportation facilities such as dual lane/ railroad overpass, roads, and flyovers, including airports can be seen as a referee to safeguard religion ( $\underline{\text { hifzh }}$ al-dinn), soul ( $\underline{\text { hifzh }}$ al-nafs), descendants ( iffzh al-nasl), and reason (

Based on the above study, if the practice of debt through PBS sukuk to build infrastructure in Indonesia is associated with the ideology of dharûriyyah (basic needs), hâjiyah (ordinary needs) or tahsiniyyah (additional needs), then the law of debt, in this case, is a permissible case. This is because the need for debt to finance infrastructure projects can be classified as dhharûriyyah needs (urgent needs).

\section{g. The Role of PBS Sukuk in Accelerating Infrastructure Development in Indonesia}

The Indonesian government continues to increase productive spending, especially for the construction of infrastructure connecting between regions, the construction of facilities and electricity infrastructure, housing, sanitation, and clean water. ${ }^{41}$ This can be seen from the infrastructure financing budget which continues to increase from year to year, as displayed below. ${ }^{42}$

${ }^{39}$ Hariyanto, 'Efektivitas Penerbitan Sukuk Negara Sebagai Instrumen Pembiayaan APBN', p. 1.

${ }^{40}$ Ikhsan Rifaldi, S.ST.Ak., M.Si, in a meeting with the author, 2018.

${ }^{41}$ Reifa Qisthi Mitsaliyandito and Tika Arundina, 'Dynamic Relationship between Sovereign Bond and Sukuk Market Developments in Indonesia', 26 (2018), 27-38 (pp. 34-35).

${ }^{42}$ Eri Hariyanto, 'Memahami Project Based Sukuk (PBS)', Direktorat Jenderal Pengelolaan Pembiayaan dan Risiko Kementerian Keuangan, 2017 <https://www.djppr.kemenkeu.go.id/page/ load/1807> [accessed 23 March 2019]. 
Table 1: Infrastructure financing budget from year to year

\begin{tabular}{cccc}
\hline Year & Allocation in APBN & APBN Expenditure & Percentage \\
\hline 2013 & 184.4 & $1,683.0$ & 11.0 \\
\hline 2014 & 206.6 & $1,876.9$ & 11.0 \\
\hline 2015 & 290.3 & $2,019.8$ & 14.4 \\
\hline 2016 & 317.0 & $2,083.0$ & 15.2 \\
\hline 2017 & 346.6 & $2,070.5$ & 16.7 \\
\hline
\end{tabular}

Source: Ministry of Finance of the Republic of Indonesia

Indonesian economic experts estimate the need for funds to increase Indonesia's economic growth until the end of 2019 reaches around Rp.2,900 trillion. To meet this need, the Government promotes the relationship between the private sector and the pattern of cooperation between the government and the private sector, including State-Owned Enterprises (BUMN). ${ }^{43}$

In addition to these steps, the Government also made breakthroughs by gathering community participation in financing the country's development. through the issuance of a Sovereign Sukuk specifically for infrastructure financing (Project Based sukuk). As discussed in Act Number 19 of 2008 concerning Government Islamic Securities or Sovereign Sukuk, Sovereign Sukuk can be issued to finance the general budget deficit and finance government infrastructure.

This government effort received a positive response from the public as indicated by the increase in PBS issuance from year to year as shown in the following table ${ }^{44}$ :

${ }^{43}$ Hariyanto, 'Memahami Project Based Sukuk (PBS)'; Rizky Suci Ramadayanti, Dedy Mainata, and Angrum Pratiwi, 'Peran Sukuk Negara dalam Pembiayaan Infrastruktur', Al-Tijary, 2.2 (2017), 155-76 (pp. 156-57) <https://doi.org/10.21093/at.v2i2.788>.

${ }^{44}$ Hariyanto, 'Memahami Project Based Sukuk (PBS)', p. 5. 
Table 2: Increase in PBS issuance from year to year

\begin{tabular}{ccll}
\hline No & Year & $\begin{array}{c}\text { Budget } \\
\text { (trillion) }\end{array}$ & \multicolumn{1}{c}{ Type of Projects } \\
\hline 1 & 2013 & IDR 0,7 & Construction of a double-track railway \\
\hline 2 & 2014 & IDR 1,371 & $\begin{array}{l}\text { Construction of the double-track railroad and } \\
\text { construction of the Hajj hostel }\end{array}$ \\
\hline 3 & 2015 & IDR 7,135 & $\begin{array}{l}\text { Construction of elevated track railways, construction } \\
\text { of the State Islamic University (UIN) campus, } \\
\text { construction of religious affairs offices and marriage } \\
\text { halls. }\end{array}$ \\
\hline 4 & 2016 & IDR 13,677 & $\begin{array}{l}\text { Construction of double track and railroad overpasses, } \\
\text { construction of roads and flyovers across Sumatra, } \\
\text { construction of UIN campus, haj hostel and religious } \\
\text { affairs office. }\end{array}$ \\
\hline 5 & 2017 & IDR 16,76 & $\begin{array}{l}\text { Implementation of train services, construction of } \\
\text { roads and water resources, construction of UIN } \\
\text { campus, Hajj hostel and religious affairs office. }\end{array}$ \\
\hline
\end{tabular}

Source: Directorate of Sharia Finance, 2016

The increasing PBS budget that is budgeted by the government from year to year, proves that PBS does not only have a role in helping the government in economic development, ${ }^{45}$ but also shows that investor acceptance of instruments using the concept of sharia in the capital market has also increased. ${ }^{46}$ The advantage of PBS compared to conventional funding systems or foreign party loans is that it can provide solutions that cannot be done by other systems namely anti-usury. This is evidenced by the case that occurred in 2013, where one project in the transportation department in Indonesia, whose funding was sourced from foreign loans, was the most problematic project at the time. But when the project funding was taken over using the PBS sukuk instrument, the problem

${ }^{45}$ Hariyanto, 'Efektivitas Penerbitan Sukuk Negara Sebagai Instrumen Pembiayaan APBN', pp. 95-96.

${ }^{46}$ Muhammad Ardi, 'Pengaruh Sukuk Terhadap Pertumbuhan Ekonomi Indonesia', Iqtishaduna, 9.1 (2018), 85-97 (P. 96). 
was resolved well. ${ }^{47}$

It is difficult to argue that PBS sukuk has good potential to assist the country in infrastructure development. On April 27, 2015, the total value of the outstanding sovereign sukuk was around Rp.245,165760 trillion. Of the total outstanding sukuk, SPNS sukuk only ranged $1.63 \%$, IFR sukuk 6.77\%, PBS sukuk 23.2\%, retail sukuk 28.5, SNI sukuk 26.35\% and SDHI sukuk 13.58\%. In this composition, although PBS sukuk ranks third in the percentage of sukuk series that have outstanding compositions, the trend for sukuk that continues to increase is PBS series sukuk. ${ }^{48}$

The following is a diagram of outstanding sovereign sukuk in trillion rupiahs as of May 31, $2018^{49}$ :

Diagram 2: Outstanding Sovereign Sukuk

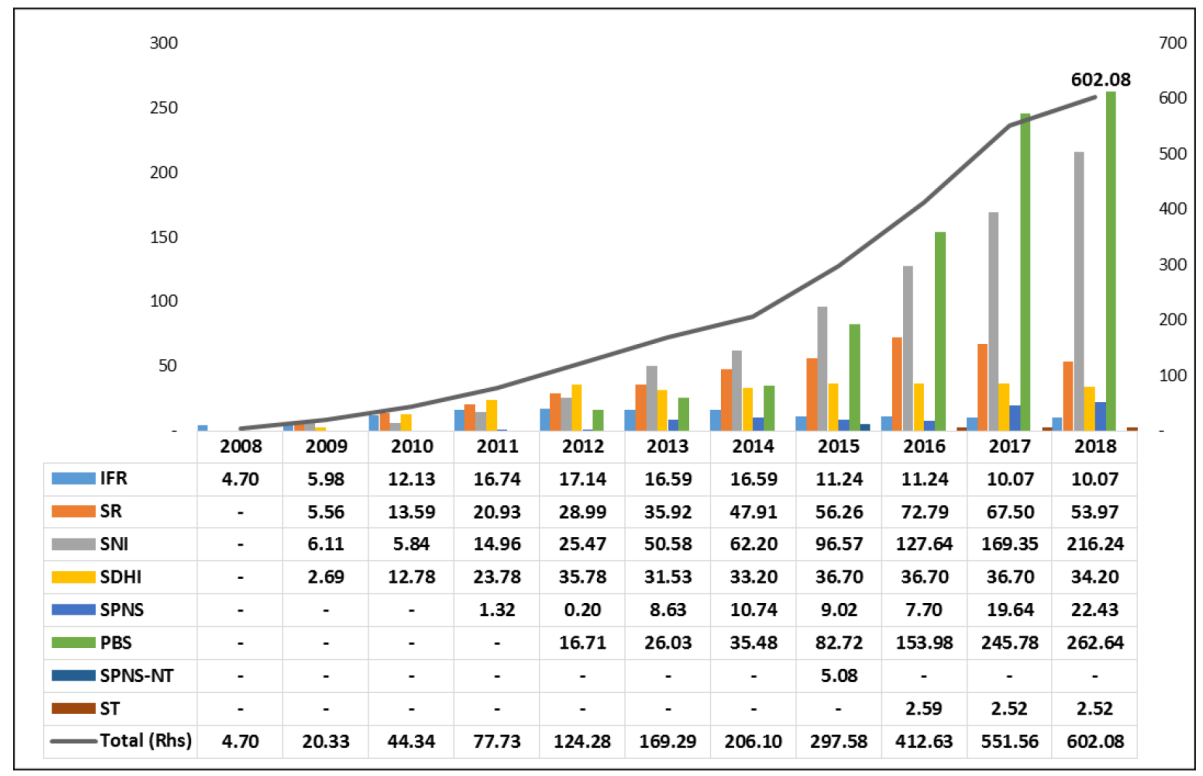

Source: Directorate of Sharia Financing, Directorate General of Financing and Risk Management, Ministry of Finance of the Republic of Indonesia, 2018.

${ }^{47}$ Manggiarto, D.S, issue PBS sukuk, in an interview, 2015.

${ }_{48}$ Manggiarto D.S, issue PBS sukuk, in an interview, 2015.

${ }^{49}$ Anggoro Pridityo, 'File PowerPoint Sukuk Negara Market Update as of May 31, 2018', 2018. 
The diagram above shows that the outstanding PBS sukuk continues to increase every year. The most significant increase occurred in 2016 to 2018, because in the past three years the composition of outstanding PBS sukuk was in the highest position compared to other sovereign sukuk. As of May 31, 2018, data showed that the outstanding sovereign sukuk was Rp.602.08 trillion (18 percent of the total outstanding government securities). In this composition, PBS sukuk has a portion of 7.8 percent from 18 percent of the total outstanding sovereign sukuk.

Diagram 3: The Percentage of Sovereign Sukuk Outstanding in 2018

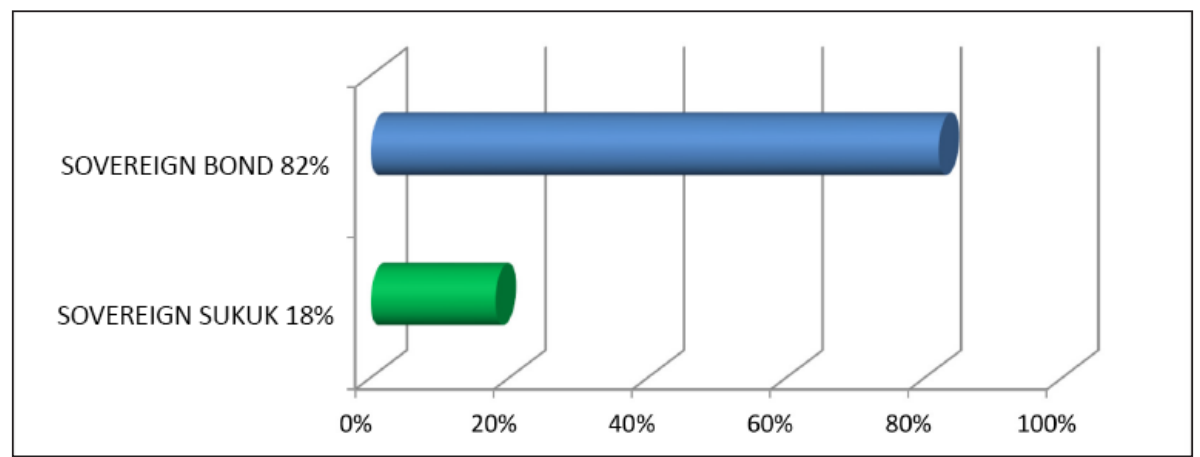

Source: Directorate of Sharia Financing, Directorate General of Financing and Risk Management, Ministry of Finance of the Republic of Indonesia, 2018.

Although the data in diagram 3 shows that the outstanding sovereign sukuk is much smaller than the outstanding state bonds, which is 18 percent compared to 82 percent, the development of sovereign sukuk has increased quite well from year to year (as illustrated in diagram 2). This shows that the Islamic financial market in Indonesia and the Sharia sukuk market continue to develop rapidly, even though its size compared to the conventional market is still very small..$^{50}$

${ }^{50}$ Anik and Iin Emy Prastiwi, 'Pengembangan Instrumen Sukuk dalam Mendukung Pembangunan Infrastruktur', Jurnal Ilmiah Ekonomi Islam, 3.03 (2017), 173-80 (p. 173) < https:// doi.org/10.29040/jiei.v3i03.129>. 
Diagram 4: The Percentage of Outstanding each type of Sovereign Sukuk from Total Government Securities in 2018

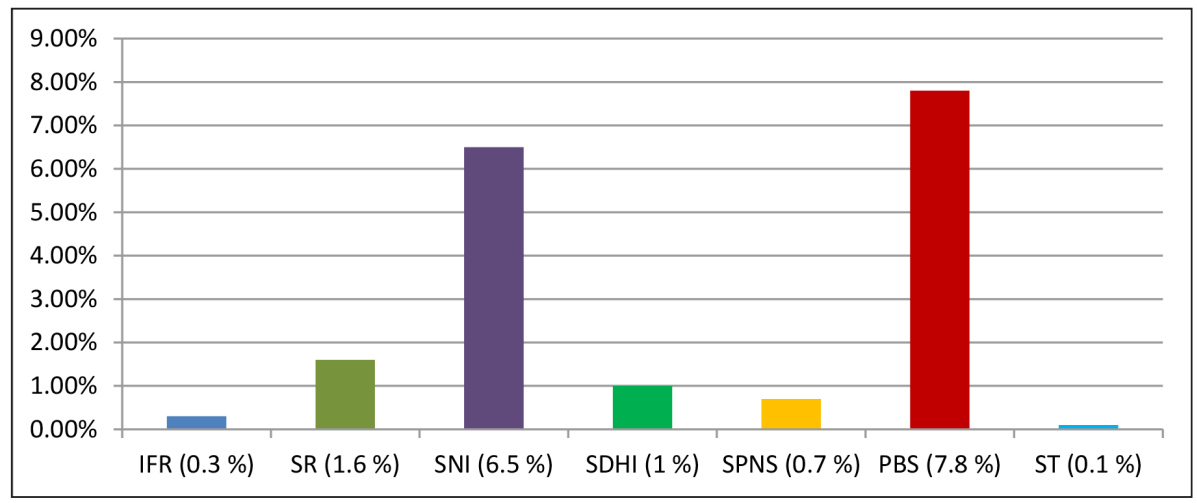

Source: Results of Data Processing from the Sharia Financing Directorate, Directorate General of Financing and Risk Management, Ministry of Finance of the Republic of Indonesia, 2018.

This data shows the increase in outstanding PBS sukuk from year to year; even in the last two years, 2017-2018, the outstanding is at the top compared to other types of sovereign sukuk. This shows that the role of PBS sukuk that is devoted to funding state infrastructure development is increasingly clear in assisting the Government of Indonesia in covering the needs of development funds. This phenomenon is an opportunity for Islamic financial institutions or Indonesian Muslim financiers to invest their funds in developing the Indonesian state from the aspect of infrastructure through a product that has sharia concept. For those who are religious and are afraid to invest their funds in fields containing usury, there are other alternatives for choosing transactions that are sharia-based. ${ }^{51}$

\section{Conclusion}

To cover the needs of the infrastructure financing budget that continues to increase from year to year, the Government of Indonesia is

${ }^{51}$ Juaris, Raja Masbar, and Chenny Seftarita, 'Analysis of The Effect of Monetary Policy on Government Sharia Securities (SBSN) in Indonesia', Sriwijaya International Journal of Dynamic Economics and Business, 2.2 (2018), 109-22 <https://doi.org/10.29259/sijdeb.v2i2.109-122>. 
innovating by issuing a special sovereign sukuk for infrastructure financing (Project Based Sukuk) based on sharia.

In its development, it turns out that the issuance of PBS has received a positive response from investors in the capital market as indicated by the increasing PBS budget that is budgeted by the government from year to year. This proves that PBS has a role in helping the government to develop the country's economy while showing that the instrument which is designed by using the concept of sharia is increasingly in demand by investors so that it will gradually reduce the concept of usury that has been circulating in the capital market.

\section{Bibliography}

Abadi, Totok Wahyu, Nunung Prajarto, and dan Budi Guntoro, 'Performance E-Government Untuk Peningkatan Partisipasi Masyarakat dalam Pembangunan Infrastruktur di Kabupaten Sidoarjo', Jurnal Kawistara, 4.3 (2014) <https://doi.org/10.22146/ kawistara.6379>

Abdullah, Hayat, 'Realokasi Kebijakan Fiskal: Implikasi Peningkatan Human Capital dan Pembangunan Infrastruktur terhadap Pertumbuhan Ekonomi dan Kesejahteraan Masyarakat', Jurnal Bina Praja: Journal of Home Affairs Governance, 6.2 (2014), 117-28 <https://doi.org/10.21787/jbp.06.2014.117-128>

Afriyenis, Winda, 'Perspektif Ekonomi Islam Terhadap Utang Luar Negeri Pemerintah dalam Pembangunan Ekonomi Indonesia', Maqdis : Jurnal Kajian Ekonomi Islam, 1.1 (2016), 1-16

Anik, and In Emy Prastiwi, 'Pengembangan Instrumen Sukuk dalam Mendukung Pembangunan Infrastruktur', Jurnal Ilmiah Ekonomi Islam, 3.03 (2017), 173-80 <https://doi.org/10.29040/jiei. v3i03.129>

Ardi, Muhammad, 'Pengaruh Sukuk Terhadap Pertumbuhan Ekonomi Indonesia', Iqtishaduna, 9.1 (2018), 85-97

Ariza, Anggatia, 'Pengaruh Pertumbuhan Ekonomi dan Belanja Modal Terhadap Indeks Pembangunan Manusia (IPM) dalam Perspektif 
Islam', Al-Maslahah, 12.1 (2016) <https://doi.org/10.24260/ Almaslahah.V12i1.348>

Beik, Irfan Syauqi, 'Memperkuat Peran Sukuk Negara dalam Pembangunan Ekonomi Indonesia', AL-INFAQ, 2.2 (2011) <http://ejournal.uikabogor.ac.id/index.php/al-infaq/article/view/80> [accessed 23 March 2019]

D.S, Manggiarto, issue PBS sukuk, in an interview, 2015

Fitria, Tira Nur, 'Kontribusi Ekonomi Islam dalam Pembangunan Ekonomi Nasional', Jurnal Ilmiah Ekonomi Islam, 2.03 (2016) < https://doi. org/10.29040/jiei.v2i03.3>

Hariyanto, Eri, 'Efektivitas Penerbitan Sukuk Negara Sebagai Instrumen Pembiayaan APBN', Indonesian Treasury Review: Jurnal Perbendaharaan, Keuangan Negara dan Kebijakan Publik, 2.1 (2017), 79-98 <https://doi.org/10.33105/itrev.v2i1.15>

—, 'Memahami Project Based Sukuk (PBS)', Direktorat Jenderal Pengelolaan Pembiayaan dan Risiko Kementerian Keuangan, 2017 <https://www.djppr.kemenkeu.go.id/page/load/1807> [accessed 23 March 2019]

Indriasari, Ika, 'Analisis Pemilihan Sukuk Sebagai Instrumen Investasi', Stability: Journal of Management and Business, 1.1 (2018) <https:// doi.org/10.26877/sta.v1i1.2619>

Juaris, Raja Masbar, and Chenny Seftarita, 'Analysis of The Effect of Monetary Policy on Government Sharia Securities (SBSN) in Indonesia', Sriwijaya International Journal of Dynamic Economics and Business, 2.2 (2018), 109-22 <https://doi.org/10.29259/sijdeb. v2i2.109-122>

'KH Ma’ruf Amin: Indonesia Bukan Negara Islam, Tetapi Negara Kesepakatan' $<$ https://nasional.kompas.com/read/2017/10/10/08462301/kh-marufamin-indonesia-bukan-negara-islam-tetapi-negara-kesepakatan> [accessed 23 March 2019]

Kogoya, Teraik, Benu Olfie, and Olly Esry Laoh, 'Partisipasi Masyarakat Terhadap Pembangunan Infrastruktur Jalan Desa Di Kabupaten Lanny Jaya-Papua', Jurnal Berkala Ilmiah Efisiensi, 15.02 (2015) 
<https://ejournal.unsrat.ac.id/index.php/jbie/article/view/8343> [accessed 23 March 2019]

Maryaningsih, Novi, Oki Hermansyah, and Myrnawati Savitri, 'Pengaruh Infrastruktur Terhadap Pertumbuhan Ekonomi Indonesia', Buletin Ekonomi Moneter dan Perbankan, 17.1 (2014), 62-98 <https://doi. org/10.21098/bemp.v17i1.44>

Meilita Evita, Fiona Lamari, Ayomi Dita Rarasati, 'An Exploratory Study of Sukuk Utilisation for Transportation Infrastructure Development in Indonesia', Makara Journal of Technology, 22.1 (2018), 53-59 $<$ https://doi.org/10.7454/mst.v22i1.3581>

Mitsaliyandito, Reifa Qisthi, and Tika Arundina, 'Dynamic Relationship between Sovereign Bond and Sukuk Market Developments in Indonesia', 26 (2018), 27-38

Mohamad, Muhammad Hisyam, 'Pendekatan Islam dalam Pengurusan Hutang', in Paradigma Ekonomi \& Integrity: Sudut Pandang Islam. Kuala Lumpur: Penerbit Institut Kefahaman Islam Malaysia (IKIM), 2014.

Nopijantoro, Wurjanto, 'Surat Berharga Syariah Negara Project Based Sukuk (SBSN PBS): sebuah Instrumen Alternatif Partisipasi Publik dalam Pembiayaan Infrastruktur', Substansi: Sumber Artikel Akuntansi Auditing dan Keuangan Vokasi, 1.2 (2018), 390-406 <https://doi. org/10.35837/subs.v1i2.259>

Nurlita, Anna, 'Investasi di Pasar Modal Syariah dalam Kajian Islam', Kutubkhanah, 17.1 (2015), 1-20

Posumah, Ferdy, 'Pengaruh Pembangunan Infrastruktur Terhadap Investasi di Kabupaten Minahasa Tenggara', Jurnal Berkala Ilmiah Efisiensi, 15.3 (2015) <https://ejournal.unsrat.ac.id/index.php/jbie/article/ view/8776> [accessed 23 March 2019]

'Presiden Joko Widodo' <https://www.facebook.com/story.php?story_fbi $\mathrm{d}=756335784555273 \& \mathrm{id}=390581294464059>$ [accessed 23 March 2019]

'Presiden Jokowi: Infrastruktur Untuk Pertumbuhan Ekonomi Lebih Tinggi' <https://www.kemenkeu.go.id/publikasi/berita/presiden-jokowi- 
infrastruktur-untuk-pertumbuhan-ekonomi-lebih-tinggi/> [accessed 23 March 2019]

Pridityo, Anggoro, 'File PowerPoint Sukuk Negara Market Update as of May 31, 2018', 2018

Putra, Adris A., and Susanti Djalante, 'Pengembangan Infrastruktur Pelabuhan dalam Mendukung Pembangunan Berkelanjutan', Jurnal Ilmiah Media Engineering, 6.1 (2016) <https://ejournal.unsrat.ac.id/ index.php/jime/article/view/11627> [accessed 23 March 2019]

Ramadayanti, Rizky Suci, Dedy Mainata, and Angrum Pratiwi, 'Peran

Sukuk Negara dalam Pembiayaan Infrastruktur', Al-Tijary, 2.2 (2017), 155-76 <https://doi.org/10.21093/at.v2i2.788>

Rifaldi, S.ST.Ak., M.Si, Ikhsan, in a meeting with the author, 2018

Rosyidah, Norma, 'Optimalisasi Fungsi Barang Milik Negara (BMN) Melalui Sukuk Sebagai Instrumen Pembiayaan Nasional', Jurnal Ekonomi dan Bisnis Islam (Journal of Economics and Business Islamic), 1.2 (2016), 161-72 <https://doi.org/10.20473/jebis.v1i2.1436>

S. Shahida, Dzubaidah Bt Zainal Abidin, 'Sukuk "Asset-Based" Berbanding Sukuk "Asset-Backed": Kes Kemungkiran Sukuk" (Paper, Persidangan Kebangsaan Ekonomi Malaysia ke VIII (PERKEM VIII), 2019).

Sanep Ahmad, Surtahman Kastin Hasan, Ekonomi Islam: Dasar dan Amalan, Ed. 2. Kuala Lumpur: Dewan Bahasa dan Pustaka, 2005. Schwab, Ed., Klaus, The Global Competitiveness Report 2014-2015. Geneva: The World Economic Forum, 2014. , The Global Competitiveness Report 2017-2018. Geneva: The World Economic Forum, 2017.

Siamat, ed., Dahlan, Sukuk Negara: Instrumen Keuangan Berbasis Syariah. Jakarta: Direktorat Pembiayaan Syariah, Direktorat Jenderal Pengelolaan Utang, Kementerian Keuangan RI, 2014.

Soenjoto, Arie Rachmat, and Hilda Lutfiani, 'Konsep dan Aplikasi Sukuk Negara dalam Pembiayaan Defisit APBN di Indonesia', Islamic Economics Journal, 2.2 (2016) <https://doi.org/10.21111/ iej.v2i2.1389> 
Sukma, Andrio Firstiana, 'Efek Pengganda Infrastruktur Pekerjaan Umum dalam Perekonomian Provinsi Bali (Multiplier Effect of Public Works Infrastructure in Bali Province)', Journal of Regional and City Planning, 26.2 (2015), 100-110-110 <https://doi.org/10.5614/ jpwk.2015.26.2.3>

Syariah, Direktorat Pembiayaan, Kumpulan Fatwa Dewan Syariah Nasional - Majelis Ulama Indonesia Terkait Surat Berharga Syariah Negara (Sukuk Negara), Ed. 4. Jakarta: Kerjasama Kementerian Keuangan RI dengan Dewan Syariah Nasional - Majelis Ulama Indonesia, 2014.

Wisudanto, Erika Sefila Putri, 'Struktur Pembiayaan Pembangunan Infrastruktur di Indonesia Penunjang Pertumbuhan Ekonomi' (Presented at the Simposium I Jaringan Perguruan Tinggi untuk Pembangunan Infrastruktur Indonesia, Paper, Simposium I Jaringan Perguruan Tinggi untuk Pembangunan Infrastruktur Indonesia, 2016), pp. 222-28

Zulfikar, Waluyo, 'Dampak Sosial, Ekonomi dan Politis dalam Pembangunan Bandara Udara Kertajati di Kabupaten Majalengka', Jurnal Caraka Prabu, 1.01 (2017), 58-77. 